This work is licensed under a

Creative Commons Attribution-NonCommercialNoDerivs 3.0 Licence.

To view a copy of the licence please see:

http://creativecommons.Org/licenses/by-nc-nd/3.0/ 


$$
\square
$$




$$
\text { Cov } 281695
$$

Working Paper 541

\section{Corruption, Firm Growth and Export Propensity in Kenya}

Peter Kimuyu

Director, School of Economics

University of Nairobi

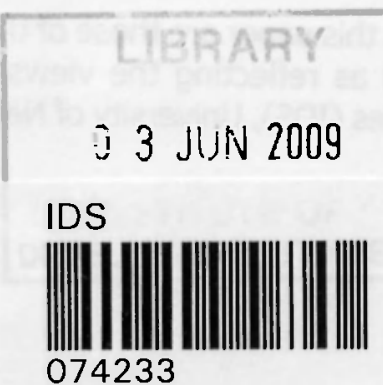




\section{Address all inquiries to}

Institute for Development Studies

University of Nairobi

P.O. Box 30197, 00100

00100 GPO, Nairobi, Kenya.

Telephone: 254020247968

Mobile: 0733-524903

0722-499706

Fax: $\quad 254020222036$

Email: idsdirector@swiftkenya.com

URL: www.uonbi.ac.ke/faculties/ids

Working Paper 541

Corruption, Firm Growth and Export

Propensity in Kenya

by

Peter Kimuyu

Email pkimuyu@africaonline.co.ke

Technical Editor: Kibisu-Kabatesi

This paper is not for quotation without permission as specified in the Copyright Act, Cap. 130, the Laws of Kenya.

Copyright @ 2006 Institute for Development Studies (IDS), University of Nairobi.

Views expressed in this paper are those of the author and should not be interpreted as reflecting the views of the Institute for Development Studies (IDS), University of Nairobi. 


\section{Acknowledgement}

Comments by Michael Schluter of the Jubilee Centre, Cambridge and participants during an IDS seminar are acknowledged. Gratitude goes to the technical Editor, Kibisu-Kabatesi and the typesetter, Judith Ndirangu both of Institute for Development Studies (IDS), University of Nairobi. 


\begin{abstract}
Manufacturing firms in Kenya spend an average of $7.5 \%$ of their annual sales on bribery, and as much as $14 \%$ of the value of government contracts on kick-backs. These averages mask significant sector, location and size differences in the exposure to corruption. Networking with public servants somewhat shields firms against corruption but that with politicians deepens exposure. Corruption does not fast-track access to public services and does not, therefore, play any greasing function. Rather, corruption significantly dampens firm growth and the propensity to export, implicitly reducing returns to investment and employment. It also adds to the cost of doing business, reducing Kenya's competitiveness and critically undermining the country's development prospects. These findings uphold others that have demonstrated the deleterious consequences of corruption, and provide further reason for intensifying the fight against the vice. In the circumstance, there is value in exploring ways of dismantling bureaucratic discretion and control rights on which corruption thrives. Furthermore, sustaining the program of privatisation of state corporations and utility companies would create space for expanding services, ameliorate capacity restrictions, obviate service-stretching, inject competition in the provision of services and reduce rents that are the objects of corruption.
\end{abstract}


IDS Working Paper No. 541

\section{Corruption, Firm Growth and Export Propensity}

in Kenya

\section{Introduction}

Surveys of manufacturing firms over the last decade have shown that businesspersons in Kenya view corruption as a major hurdle to business pursuits.' Other governance-related surveys have also concluded that Kenya is an increasingly corrupt country. Recognising this state of affairs, the new government shifted the fight against corruption into centre stage soon after coming to power, and has legislated accordingly. Unfortunately, the fight against corruption has not benefited from hard evidence about who is most exposed to corruption and how such exposure is structured. Furthermore, there is very little concrete evidence on the retrogressive consequences of corruption. Because business persons are now more open about the vice, it is possible to gather high quality corruption-related data and subject such data to rigorous analysis to build the stock of knowledge on which the fight against corruption can be founded. This is the primary motivation of our paper.

Two data-related developments are driving current empirical analysis on corruption and economic performance namely, the availability of country-level corruption indices and rich firm-level 
IDS Working Paper No. 541

data. Analyses based on corruption indices have demonstrated conclusively that corruption reduces the investment/GDP ratios (Mauro 1995), discourages direct foreign investment (Wei 1997) and generally hurts economic growth (Mauro 1995, Wei 1999). This type of literature also concludes that corruption skews public expenditure away from priority projects to projects susceptible to bribery-related manipulations, undermines the productivity of public investment and compromises government's ability to collect tax revenues (Tanzi and Davoodi 1998). Corruption also creates an entry barrier that makes markets less contestable and adds to the cost of starting and doing business. Firms that win bids in a corrupt environment produce outcomes of connections rather than efficiency. Beyond a certain threshold, corruption begets more corruption, so that legitimate business investment is discouraged (McArthur 2000). It has also been suggested that corruption lowers welfare because the cost of corruption adds to the overall cost of production (Cooksey et al, 2000). Where corruption abounds, consumption falls and poverty is intensified because the poor are - denied equitable access to social services.

Although availability of corruption indices permits cross-country analysis on the interplay between corruption and economic aggregates, concern has been raised about the unobservable heterogeneity across data points in cross-country comparisons 
(Fisman and Svensson 2000). Furthermore, since indices on which cross-country analyses are based are constructed from broad subjective assessments, they are fraught with perception biases. Additionally, cross-country comparisons do not generate information on the micro-implications of corruption and take the production structure of firms as given. They are also faulted for failing to distinguish between different levels and forms of corruption (McArthur 2000).

These shortcomings have been somewhat addressed in works that exploit firm-level data to lay a firmer foundation for understanding the interplay between corruption and firm performance. Building on theoretical frameworks that perceive corrupt bureaucrats as maximizers of bribery subject to the possibility that they may either be caught or that bribe extraction may force firms out of business (Fisman and Svensson 2000; Svensson 2000; McArthur 2000), firm-level analysis has demonstrated that firms typically pay bribes when dealing with public servants especially in the course of exporting, importing, and acquisition of infrastructure services and that amounts paid depend on the firm's ability to pay (Svenssion 2000), that corruption reduces the short-run growth rates of firms (Fisman \& Svensson 2000 ) and that while broad levels of corruption do not affect firm-level performance, corruption in public service provision 
reduces firm-level productivity and distorts the pattern of accumulation of capital (McArthur 2000).

However, many firm-level surveys often mop-up firms in different activities so that technology-related heterogeneity is likely to persist and probably lead to wrong conclusions. This paper somewhat refines and extends the analysis on corruption and firm behaviour by; (a) focusing specifically on manufacturing firms to obviate some of the heterogeneity problems, (b) using data that pools information from firms of different sizes, (c) exploiting a richer idiosyncratic dimension of a recent manufacturing survey, and (d) expanding the set of firm performance indicators to include export performance.

We use the Investment Climate Assessment survey data for Kenya gathered by the Kenya Institute for Public Policy Research and Analysis in collaboration with the Regional Program for Enterprise Development (RPED) of the World Bank during March - July 2003. A random sample developed on the basis of census data from the Central Bureau of Statistics (CBS) was used.

The sample frame was an outcome of several steps. First, a list of registered manufacturing firms was compiled by the Central 
Bureau of Statistics (CBS), Ministry of Planning and National Development. Some firms were deleted from the list after controlling for location and sector. This frame was stratified on the basis of size, location and sub-sector. To adequately reflect geographical distribution, five regions were defined including Nairobi Area that extended to the environs of the city, Mombasa, Nakuru, Eldoret and Kisumu. To obtain appropriate distribution of manufacturing activities, the ISIC classification was used to define nine distinct activities that included Agro-industry, Chemicals and Paints, Construction Materials, Furniture, Metals, Paper, Publishing and Printing Industry, Plastics, Textile and Leather Products and Wood.

In line with other RPED data sets, five size classes were identified, namely; Very Small (1-10 employees), Small (11-49 employees), Medium (50-99 employees), Large (100-499 employees) and Very Large (500 or more employees). The location, size and sectors of activities were used to define clusters, out of which firms were random selected. Owing to numerous refusals, the actual number of firms interviewed was 282 from a sample of 368 listed firms. Data massaging further reduced the working sample to 279 firms. 
IDS Working Paper No. 541

The survey instrument had eight modules, namely; Entrepreneurship and Business History, Technology, Trade, Infrastructure, Business Environment, Production and Sales, Credit and Finance, Labour and Training. The business environment module included questions that generated information on corruption as indicated below:

a. In 2002, what would you estimate as the total amount spent by a typical establishment in your industry in 'unofficial payments' for public utilities, telephones and licences from public institutions including the central government?

b. What about for licenses from government institutions?

c. How about unofficial payment in respect of other services?

d. How much do you estimate unofficial payments are as a percentage of annual revenue for a typical firm in your industry?

e. When establishments in you industry do business with the government or local authorities, what percentage of the contract value is typically expected in gifts or unofficial payments to secure the contract? 
IDS Working Paper No. 541

Often, concern is raised about whether reliable data on corruption can be collected in spite of the inclusion of these carefully crafted questions in the survey instrument, and given the secretive nature of corrupt activities (Fisman and Svensson 2000). We believe that in our case, this concern was mitigated through a variety of data collection strategies. Previous RPED surveys had already introduced Kenyan manufacturers to discussion on corruption and managers appear progressively willing to discuss corruption issues with unusual forthrightness. The information collection strategy had also other strengths that increased the reliability of the corruption data.

First, the survey was implemented by Kenya Institute of Public Policy Research and Analysis (KIPPRA), a semi-autonomous think-tank with a good rapport with Kenya's private sector. ${ }^{2}$ Implementation of the survey by KIPPRA meant that the survey was conducted by an organisation that the private sector could trust.

Second, questions on the general business environment, of which corruption related questions were a part, were strategically placed in the questionnaire, so that there was enough of other lesssensitive questions to improve rapport with the respondents before posing corruption questions. Third, multiple questions on corruption 
were asked to improve on the reliability and lastly, the questions were posed indirectly to avoid implicating the respondent of any wrongdoing.

In Section 2 we review some of the recent literature on corruption, and then turn to the sample characteristics and locus of corruption in Section 3. In Section 4 we explore the structure of corruption before finding out the specific impact of corruption on firm growth and export propensity in Section 5. Section 6 concludes the paper.

\section{A Review of Corruption Literature}

Shleifer and Vishany (1993) define corruption as the sale of government property by public officials for personal gain. Corruption can be either petty or systemic. It is petty when honesty is the norm so that corrupt acts are exceptional and dishonest officials invariably punished when detected. On the other hand, corruption is systemic when it involves a large pool of individuals who habitually and cooperatively engage in dishonest acts. Social sanctions against corruption diminish as corruption becomes increasingly systemic since honest individuals become exceptions and find it increasingly hard to do honest business, phantom firms are established for purposes of corrupt deals, and reputation matters increasingly less. 
Models explaining interactions between entrepreneurs and bureaucrats range from the 'invisible hand' that assumes relatively benevolent, well organised and un-corrupt governments to the 'grabbing-hand' that views governments as disorganised, interventionist and corrupt (Frye \& Shleifer 1997). In between, we encounter the 'helping hand' model that assumes intimate involvement of public servants in promoting private economic activity through selective pursuit of unified industrial policies. The 'grabbing hand' model, often validated in situations characterised by a large bureaucracy of independent public servants pursuing private interest without concern over unified policy stances, describes the environment in which corruption best thrives.

The 'principle agent' and 'crime and punishment' models typically inform the analysis of determinants of corruption. On the crime side, a public servant is assumed to compare expected utilities from legal and illegal behaviour. On the punishment side, the probabilities of detection and punishment are put into consideration in comparing expected utilities. This crime-punishment model concludes that the incidence of illegal behaviour such as corruption is positively correlated with the gains from illegal activity, and negatively related with the probability of detection and punishment. The principal-agent model on the other hand regards corruption as an information problem, with a principal who is unable to control 
an agent properly. ${ }^{3}$ Monopoly powers and discretion enjoyed by public officials create information barriers that are then exploited by corrupt public servants.

Corruption can either include or exclude theft. Corruption without theft occurs when public servants turn over the entire official proceeds from sale of public service or good to government, keeping the bribe component only. On the other hand, bribery includes theft when public servants conceal the transaction altogether, passing nothing to the government. With theft, a firm pays an amount equal to the bribe, often lower than the official price (Schleifer \& Vishny 1993, Bardan 1997). Successful extraction of bribe with theft requires public servants to create artificial shortages or stretch services. Since the price charged is often lower than the official price, this form of corruption is more attractive to firms, promotes collusion between firms and bureaucrats and is harder to detect and control. By aligning the interests of firms with those of public servants, corruption with theft tends to become more generalised (Shleifer \& Vishny 1993).

Corruption is also either cost-reducing or surplus-shifting (Bliss \& Di Tella 1997), the former occurring when corrupt agents reduce the costs of acquiring a public service and demand a bribe in return. Surplus-shifting bribery is extracted when market 
surpluses known to corrupt bureaucrats are targeted. Corrupt bureaucrats and their business counterparts find cost-reducing corruption mutually beneficial even though theft is invariably involved.

Extraction of a bribe derives from bureaucratic discretion over firms. Bureaucratic control rights are outcomes of the regulatory environment. When business operations are subject to either multiple licences or subsidies, the regularity of contact between entrepreneurs and bureaucrats increases. Where issuance of licences or decisions about whom to offer subsidies is at the discretion of a bureaucrat, corruption opportunities arise. Whether or not these opportunities are exploited depends on the quality of the public servants that is in-turn closely associated with the criteria for recruitment and promotion, the level of public sector remunerations relative to those in the private and NGO sectors, and the strength of prevailing moral norms (Wei 1999; Shleifer and Vishny 1993).

Corruption contracts can also be viewed as sequential games that involve arbitrary and uncertain property rights. Corrupt agents initially look out for their likes on the other side of the transaction divide. The probability for this desirable double coincidence is assessed in every transaction and revised upwards after 
IDS Working Paper No. 541

successful bribe-extraction attempts. Such success encourages initiation of corruption in subsequent transactions (Bardan 1997). Since being reported and sacked is always a possibility, corruption is a gamble. It is also a frequency-dependant game whose expected gains depend on the number of other corrupt agents involved. The expected cost of corruption declines with the number of corrupt bureaucrats and the profitability of corruption positively correlates with its frequency (Murphy, Shleifer \& Vishny 1993).

The efficacy of bureaucratic control rights on which corruption thrives varies across sectors and locations depending on regularity and intensity of contact. Exporting firms and those that use imported raw materials often require additional licences and end up dealing with more public servants and government agencies (Svensson 2000). They are therefore more prone to bureaucratic control on this account. Since informal and small firms seldom deal with bureaucrats, bureaucratic control rights over such firms are weak. ${ }^{4}$ A similar difference can be assumed between firms located in capital cities where bureaucrats concentrate and those located in smaller cities. Other sector-specific factors that dispose firms to corruption include dependence on public infrastructure services (Fisman \& Svensson, 2000). 
The probability that a randomly selected firm is exposed to corruption is simply the probability that such a firm is matched with a corrupt bureaucrat. Whether the firm ultimately pays bribes is the outcome of a bargaining process that depends on the relative leverage that each party enjoys, as well as on the corrupt bureaucrat's bribe-extraction talents (Svensson 2000; Fisman \& Svensson 2000). Firms are poorly leveraged from bribe extraction when a large proportion of their investment is irreversible so that exit is costly. Underlying technology therefore counts (Fisman \& Svensson 2000). The danger that firms may be forced to exit act as primary deterrence against corruption.

Bureaucratic heterogeneity and competition among corrupt bureaucrats also increase a firm's leverage. The presence of even a few honest bureaucrats encourages re-application for licenses and utility connections, reduces possibilities for customising corruption-related harassment, and increases the likelihood of exposing corrupt practices. When corrupt public servants act independently, they undermine each other and in the extreme case of free entry into bribe collection, total bribes demanded from each firm simply explode and production collapses. Therefore, the very industrial organisation of corruption determines it future (Shleifer \& Vishny 1993). 
IDS Working Paper No. 541

The degree of control rights can be viewed as determining the threat point or leverage in 'negotiating' between public servants and firms. When public servants have low control rights, firms can refuse to pay the bribe without any major consequences on their operations. Where bureaucrats have high control rights, firms either pay the required bribe or are forced to exit. Control rights vary across location and sector, but are typically high for exporting firms because such firms often require additional licenses and deal with more government agencies and/or departments. They are also high for larger firms that, for reasons of size, tend to be obtrusive and bound to attract attention from public servants. On the other hand, control rights are low for informal firms that seldom deal with bureaucrats and for very small firms that are by implication less obtrusive.

There are also demand side considerations. Bribes extracted by employees of utilities are lower when capacity restrictions are ameliorated, such as when a utility parastatal is privatised (Clerk and $\mathrm{Xu} 2002$ ). This is because of a reduction in excess demand and limited opportunities for service stretching following, for example, privatisation-related capacity expansion. Privatisation gives a utility company better property rights as private owners become residual claimants of the company's income, and the incentive to reduce corruption increases. Under public ownership, 
IDS Working Paper No. 541

individuals have little incentive for monitoring employees. Privatisation increases the marginal benefit of monitoring without a corresponding increase in marginal costs. Principal-agent problems between owners and managers that may be more acute under public ownership become ameliorated through privatisation. When side payments from corrupt employees are possible, managers are unlikely to exert effort in reducing corruption. In countries where public sector salaries have been eroded by inflation and salary freezes, the threat to fire corrupt public employees lacks sufficient moral credibility.

Where there is sufficient competition, such as with multiple utility providers, demand for bribes can cause customers to switch to other providers. Competition therefore leverages customers. On the other hand, enterprises that are more profitable pay higher bribes in accordance to the endogenous harassment and queuing theories of corruption. According to the endogenous harassment theory (Kaufmann and Wei 1999), a service provider may have observable information that helps estimate a firm's maximum willingness to pay for a service and then endogenously request bribes accordingly. In this case the bribe amount expected from different firms increase with the willingness to pay for the service. 
In the endogenous harassment framework, the employees of the service provider discriminate between different service users on the basis of characteristics instrumental in the willingness to pay. Under the queuing or speed money hypothesis, enterprises selfselect the amount of bribe depending on the cost of waiting. Under the endogenous harassment hypothesis on the other hand, employees of a utility provider taking a bribe discriminate between enterprises on the basis of information about profitability and other characteristics of the firms.

Other factors related to the endogenous harassment hypothesis are that an enterprise's willingness to bribe is a function of the magnitude of overdue payments to a utility company or tax authorities. When the overdue amounts are significant, the public servants threat to either cut the service supply or take legal action is credible: the enterprise's fall back position is weakened, and the public servant is better able to extract a higher bribe than when the enterprise has no outstanding payments.

The environment in which enterprises and public servants operate has also a bearing on the inclination to offer or take a bribe, as well as the actual size of the bribe (Clarke and $\mathrm{Xu} 2002$ ). This is on account of the multiple equilibria nature of corruption. The urge for an individual to be corrupt is stronger where many people 
are corrupt. This is because the moral cost of being corrupt is low when a society is already corrupt. Since corruption tends to undermine economic performance, enforcement resources also tend to be limited in corrupt societies, and detection and punishment less likely with systemic corruption.

There are reasons why the overall corruption in a country can be high. Rents are higher in less competitive economies, so that corruption is by implication higher in such countries. Overall corruption is also higher when firms are protected from foreign competition by either policy induced barriers or natural barriers. Corruption is also higher where there are no political institutions for highlighting accountability, such as the lack of democracy and free press. Corruption is also higher in countries that are not growing rapidly so that occupational choice is affected by the system of rewarding talent. With slow economic growth, talents tend to flow towards rent seeking sectors rather than productive ones. The converse is also true: when an economy is growing fast, talent tends to flow in the direction of productive sectors. Overall corruption is therefore likely to be greater in countries that are either stagnating or growing only slowly.

From this literature, we expect to find evidence of systemic corruption and payment of high bribes. We also expect the 
incidence and sizes of bribery to functions of the firm profitability, irreversibility/opportunity cost of capital, firm size and the incidence of red-tape. We also anticipate location and sector factors on the structure of corruption.

\section{Burden and Locus of Firm-Level Corruption in Kenya}

There was a surprisingly high response rate on corruption-related questions. The entire sample of 279 firms responded to the question about the level of unofficial payments made in respect of public utilities (BRIBE1). 215 of the firms were also able to estimate the percent of annual revenue that went to unofficial payments (BRIBE). Some 197 of them also gave an estimate of the unofficial payments made in respect of business licenses (BRIBE2). However, only 140 of the firms responded to the question about the percentage of contract value made as unofficial payment on government contracts (BRIBECON). This is reasonable, since some of the firms in our sample are not likely to have received contracts with government on account of small size and line of activity..

Preliminary analysis reveals that firms spent an average of about 7.5 percent of their annual sales on bribery. This average is however subject to considerable sector and location variations. For example, firms in the 'machinery and other' sector bare the 
greatest burden, with more than $20.4 \%$ of their annual revenue being spent on such payments (Table 1). Firms in the wood and furniture sector were also badly affected as they also spent nearly $13 \%$ of revenue on unofficial payments. Firms in these two sectors contrast with those in agro-processing and chemicals/paints sectors, that spent only $1.1 \%$ and $1.12 \%$ of their annual revenue on corruption related payments respectively. Regarding kickbacks in respect of government contracts, firms pay $14.2 \%$ on average for such contracts. Firms in the construction sector pay a whooping $26 \%$ as kick-backs on such contracts while those in paper, printing and publishing firms pay as much as $25.8 \%$ of the contract value in kick-backs. Other firms that were also heavily burdened by contract related kick-backs were those in textile/ garment, metals sector and those in the wood/furniture sectors. These pay $14 \%, 13 \%$ and $12 \%$ respectively.

With regard to public services, business licenses attract higher bribery than utilities. The mean bribery paid for utilities in 2002 was Ksh36,948.00. This compares with a sample mean of Ksh44,219.00 for business licenses. Obviously, these means mask huge sub-sector differences in the burden of unofficial payment related to utilities and business licenses. Regarding the latter, actual amounts spent by firms during 2002 ranged from Ksh7,400.00 for firms in the construction-materials 
sector to an average of Ksh $156,317.00$ paid by firms in the textile and garments sub-sector. Similarly, unofficial payments in respect of utilities ranged from only Kshs8,500.00 for construction material sector to Ksh449,000 for paper, printing and publishing.

On average, senior manager of manufacturing firms spend $13.5 \%$ of their time dealing with the requirements imposed by government, including filling income tax forms, license application and so on. This translated into seven working weeks every year. The manufacturers are therefore confronted with a high incidence of red tape. This may simply be the outcome of bureaucratic stealth but on the other hand red tape may be corruption-related, proxying for time spent breaking the resolve by businesspersons not to oblige.

During 2002, manufacturing firms in Kenya received an average of 21 visits from government officials from different public institutions and departments. The highest frequency of visits was by personnel from the Kenya Revenue Authority, ostensibly related to tax assessments, and the Ministry of Labour and the National Social Security Fund. The mean number of visits from each of these government departments was five and four respectively. Other departments that frequently visited the firms were health and municipal authorities. Although there are no 
known comparative benchmarks, these frequencies and contacts between manufacturers and public servants are intense.

Manufacturing firms also require an average of three business licenses. The single business permit and trade licences are most common, acquired by 84 and 83 percent of the manufacturing firms respectively. Some of the firms also need permits for expatriate workers and import licences. On a scale of 1 to 5 from 'not a problem' to 'severe problem', firms give corruption an average rate of 3 , so that corruption is viewed as a major problem. Although the direct corruption burden appears a small proportion of annual sales, it adds to the costs of doing business in Kenya, and its indirect consequences are far reaching.

In terms of location, firms based in the capital city of Nairobi bear the brunt of corruption since firms based here pay the highest amounts of unofficial payments on most counts. In particular, firms based in Nairobi spend the highest proportion of annual sales in unofficial payments and the highest average unofficial payments for utilities and licenses (Table 3 ). Firms located in Nakuru also pay more than the average percentage of their sales in unofficial payments than firms located elsewhere. Obviously, there is greater concentration of public servants in Nairobi so that the regularity and intensity of contact between public servants and firms in greater in the capital city. The results for Nakuru 
are somewhat perplexing, except that Nakuru, the home city of the immediate former President of Kenya has a very complex system of patronage that probably translates into a high incidence of corruption. ${ }^{5}$

There is also a size factor in the locus of corruption. While very small firms do not make unofficial payments in respect of licences and other services, the medium sized firm are hardest hit by corruption and spend as much as $9 \%$ of annual sales on corruption and $18 \%$ of the value of government contracts on kick-backs. These percentages are higher than the average for the entire sample (Table 4). On the other hand, average unofficial payments for utilities and percentage of contract value by the large firms are higher than the sample averages. Ironically, the very large firms spent the smallest amounts in unofficial payments: they spend the smallest proportion of annual sales on unofficial payments. This could be a mathematical outcome since equilibrium corruption is probably less spread out than firm size.

To summarise these descriptive analyses, manufacturing firms in Kenya spent more than $7 \%$ of their total sales on bribery, and more about $13 \%$ of the value of government contracts as kickback. The burden of corruption is therefore not trivial and corruption directly adds to the cost of doing business in the country. • 


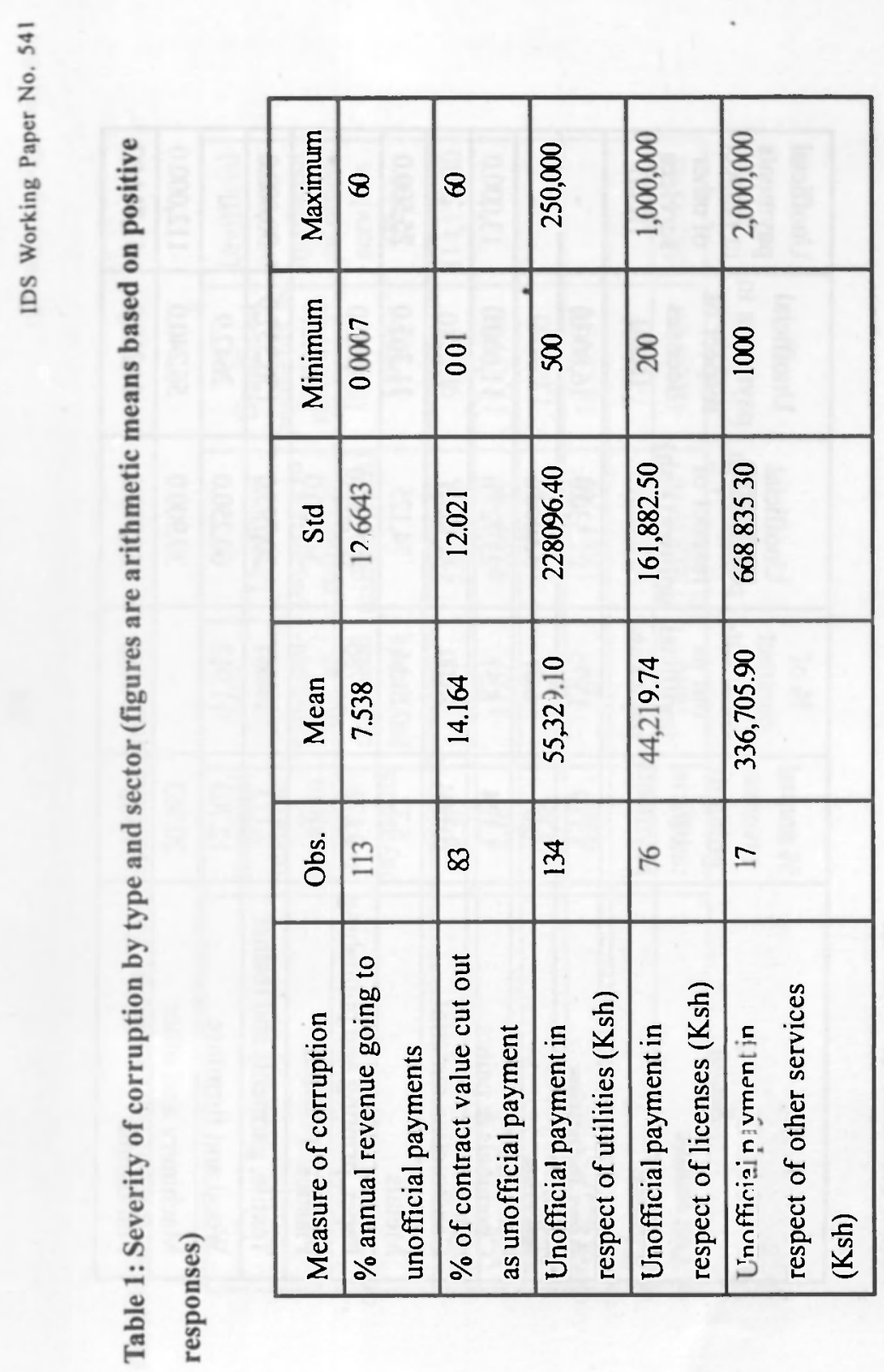


Table 2: Severity of Corruption by Type and Sector (Figures are arithmetic means)

\begin{tabular}{|l|c|c|c|c|c|}
\hline \multicolumn{1}{|c|}{ Sector } & $\begin{array}{c}\text { \% annual } \\
\text { revenue } \\
\text { going to } \\
\text { unofficial } \\
\text { payments }\end{array}$ & $\begin{array}{c}\text { \% of } \\
\text { contract } \\
\text { value cut- } \\
\text { out as } \\
\text { unofficial } \\
\text { payments }\end{array}$ & $\begin{array}{c}\text { Unofficial } \\
\text { payments in } \\
\text { respect of } \\
\text { utilities (Ksh) }\end{array}$ & $\begin{array}{c}\text { Unofficial } \\
\text { payments in } \\
\text { respect of } \\
\text { licenses } \\
\text { (Ksh) }\end{array}$ & $\begin{array}{c}\text { Unofficial } \\
\text { payments } \\
\text { in respect } \\
\text { of other } \\
\text { services } \\
\text { (Ksh) }\end{array}$ \\
\hline Agro-industries & 1.119 & 13.75 & $21,330.0$ & $16,800.0$ & - \\
\hline Bakeries & 0.01 & 6.67 & $32,000.0$ & - & - \\
\hline Chemicals \& paints & 1.124 & 8.57 & $23,727.0$ & $11,000.0$ & $13,000.0$ \\
\hline Construction material & 10.004 & 26.00 & $8,500.0$ & $7,400.0$ & - \\
\hline Metals & 5.32 & 13.14 & 74,125 & $11,363.0$ & $25,500.0$ \\
\hline Paper, printing and publishing & 9.172 & 25.786 & $449,000.0$ & $24,500.0$ & - \\
\hline Plastics & 7.01 & - & $34,000.0$ & $33,615.4$ & - \\
\hline Textile, garments and leather & 7.173 & 14.067 & $20,795.0$ & $156,357.0$ & $30,000.0$ \\
\hline Wood and furniture & 12.703 & 11.912 & $60,250.0$ & 2642.9 & - \\
\hline Machinery and other & 20.363 & - & $39,900.0$ & $56,240.0$ & $112,000.0$ \\
\hline Full sample & 7.538 & 14.165 & $36,948.0$ & $44,219.0$ & $51,714.00$ \\
\hline
\end{tabular}

Table 3: Severity of Corruption by Firm Size Categories

\begin{tabular}{|l|c|c|c|c|c|}
\hline Location & $\begin{array}{c}\text { \% annual } \\
\text { revenue } \\
\text { going to } \\
\text { unofficial } \\
\text { payments }\end{array}$ & $\begin{array}{c}\% \text { of } \\
\text { contract } \\
\text { value cut- } \\
\text { out as } \\
\text { unofficial } \\
\text { payments }\end{array}$ & $\begin{array}{c}\text { Unofficial } \\
\text { payments in } \\
\text { respect of } \\
\text { utilities (Ksh) }\end{array}$ & $\begin{array}{c}\text { Unofficial } \\
\text { payments in } \\
\text { respect of } \\
\text { licenses } \\
\text { (Ksh) }\end{array}$ & $\begin{array}{c}\text { Unofficial } \\
\text { payments } \\
\text { in respect } \\
\text { of other } \\
\text { services } \\
\text { (Ksh) }\end{array}$ \\
\hline Nairobi & 9.37 & 17.17 & $53,382.35$ & 92,783 & $114,153.80$ \\
\hline Mombasa & 2.18 & 11.67 & $40,800.00$ & $11,857.00$ & - \\
\hline Nakuru & 17.88 & 11.25 & 10.463 .00 & $1,640.00$ & - \\
\hline Eldoret & 0.06 & 7.69 & $11,217.40$ & $16,173.31$ & - \\
\hline Kisumu & - & - & 8360.00 & $7,750.00$ & - \\
\hline Full sample & 7.54 & 14.16 & $55,329.10$ & $45,131.00$ & $58,545.45$ \\
\hline
\end{tabular}




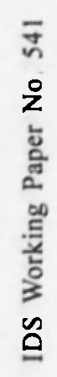

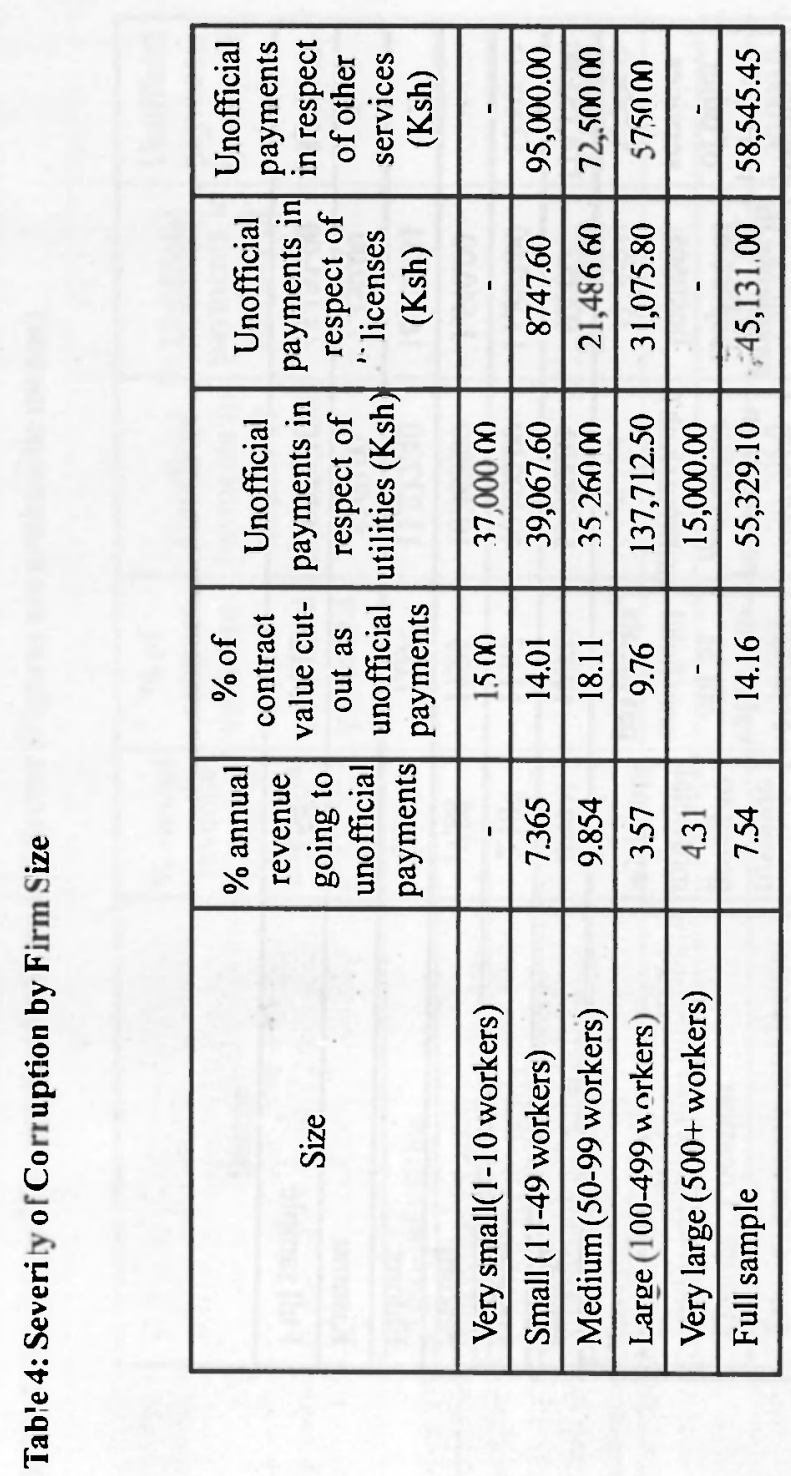


Tabte 5: Relative Burden of Corruption

\begin{tabular}{|l|c|}
\hline Cost source & $\%$ of total sales \\
\hline Cost of electricity, fuel and other energy & 35.84 \\
\hline $\begin{array}{l}\text { Cost of allowances, bonuses and other } \\
\text { allowances to employees }\end{array}$ & 11.12 \\
\hline Bribery & 7.538 \\
\hline Loss due to theft, vandalism, and arson & 6.12 \\
\hline Shipment rejected due to damage & 0.45 \\
\hline
\end{tabular}

\section{The Structure of Corruption}

Although businesspersons in Kenya are increasingly open about corruption, we expect some response bias that is likely to go in either direction. In particular, we expect that there would be firms unable to say nothing positive about the political leadership and therefore tend to exaggerate the state of corruption. On the other hand, it is possible that there would be firms that have benefited from official excesses and that are therefore likely to downplay the extent of corruption. The firm level data on corruption is therefore likely to be noisy just on account of the secretive nature of corruption despite the very exacting data collection strategy. These considerations are borne in mind in the rest of the paper.

We now turn to modelling of the structure of corruption. Regarding the dependent variable or the variable representing corruption, a number of choices are open, such as unofficial 
payments in respect of public services, unofficial payments in respect of business licences, kick-backs associated with government contracts, proportion of value of total sales going into unofficial payments and even the severity of corruption as a problem faced by business persons. We use the percentage of annual sales spent on unofficial payments in analysing the structure of corruption because this measure is more comprehensive and enjoys a high response rate. Although corruption literature has been burgeoning, confirmed regularities regarding it structure are limited so that econometric analysis of corruption presented below has to be treated as experimental.

We report results of the econometric experiments exploring exposure to corruption using the percentages of total sales spend on unofficial payments as the dependent variable (Table 6). We also cluster some of the explanatory variable around the concepts of trade (export participation and use of imported raw materials) and networking (measured by number of public servants and politicians well known and trusted enough to discuss business matters). The explanatory variables also include the proportion of tax revenue reported for tax purposes and red tape (measured by the proportion of senior managers time used in dealing with the requirements of government regulation such as taxes, customs, labour regulations, licensing and registration). 
The results show a strong inverse association between the proportion of revenue reported for tax purposes and the percentage of annual sales spent on unofficial payments. In other words, firms that report a smaller proportion of their revenue for tax purposes are more exposed to corruption, upholding the endogenous harassment hypothesis that firms that do not pay or only meet part of their statutory obligations have poor leveraging. The benefits of failure to fully meet statutory obligations are eroded by higher corruption-related vulnerability. The results on the trade variables suggest that exporting even a proportion of finished products and using imported raw materials significantly reduces a firm's exposure to corruption. This outcome is counter intuitive considering more exacting documentation requirements for international trade that in turn lead to greater interaction with the bureaucracy and greater exposure to corruption on that account.

The results further reveal that an inverse relationship between the number of public servants known and trusted and proportion of annual sales spent on unofficial payment. That with politician known and trusted is significantly positive. This outcome is particularly significant when the two network variables are included in the same model. Of particular significance is the finding that exposure to corruption increases with the number of politician 
that proprietors of manufacturing firms know and trust. Fund raising activities (popularly known as harambees) are possible conduit for such unofficial expenditures that are made in exchange for potential favours including access to government business. On the other hand, the numbers of civil servants that are known by businesspersons show a reverse effect on the proportion of total sales spent of unofficial payments. Interactions with public servants seem to reduce exposure to corruption. It would seem that manufacturers in Kenya find it necessary to invest in building acquaintances and developing mutual trust with public servants to shield themselves against the unfavourable social infrastructure that is part of the Kenyan business environment.

There is also a strong direct relationship between red tape and exposure to corruption, suggesting that paying bribery does not in any way reduce the amount of time that senior managers of manufacturing firms spend dealing with the requirements of government regulations. This outcome is robust to model specifications, and shatters the speed money or greasing function hypothesis of corruption. 


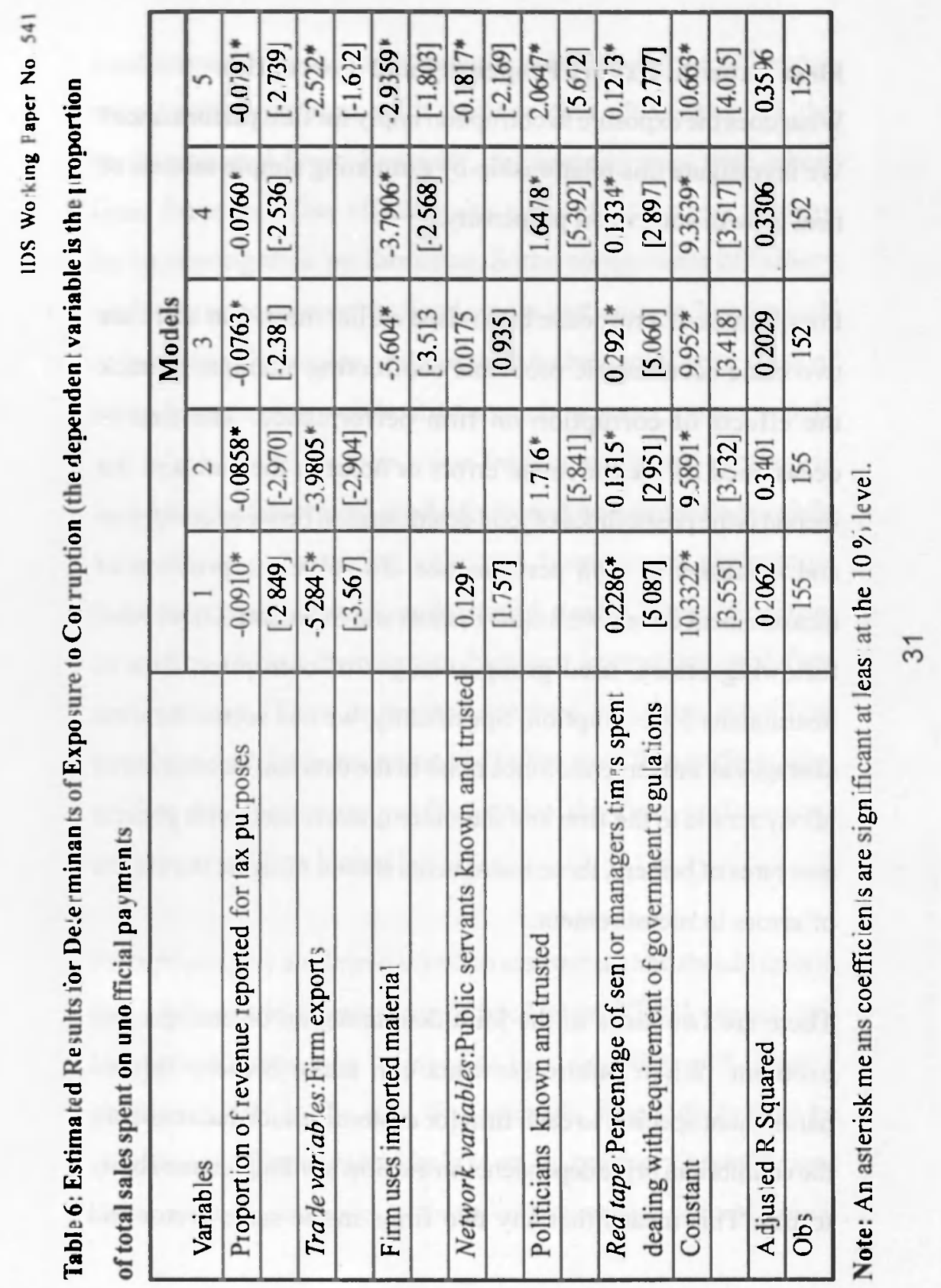




\section{Firm Growth, Export Propensity and Corruption}

What does the exposure to corruption imply for firm performance? We investigate this relationship by estimating simple models of firm growth and export propensity.

Possibilities of a response bias raised earlier mean that there are two basic econometric problems confronting attempts to track the effects of corruption on firm performance. The first is occasioned by measurement errors or noise in the data and the second is the possibilities of joint determination between corruption and measures of firm performance. To solve the problem of measurement errors, we follow Fisman and Svensson (2000) who, following others, used group averages of corruption data as instruments for corruption. Specifically, we use sector-location averages as instruments. Since noise in the data can be considered idiosyncratic to the firm and therefore uncorrelated with general measures of bribery, these instruments should mitigate the effects of errors in measurement.

There are two sides to the joint-determination or endogeneity problem. When public servants can make bribery related harassment specific to each firm (or customise such harassment), the equilibrium bribe dependents on the firm's willingness or ability to pay. This means that any two firms in the same sector and 
location could pay different amounts in bribes, and the difference may closely correlate with features that also influence the performance of firms. Secondly, endogeneity may arise where firms focus on either efficiency or rent-extraction as a strategy for increasing their performance. Some components of bribery are likely to be reasonably fixed across particular industries and/ or locations. Examples of these may include unofficial costs of being connected to public utilities such as water, power supply and telephone. Even then, some firms may choose to compete on the basis of improved productivity and new technology, while others focus on obtaining important licences and preferential market access through under-hand deals. These different strategies reduce association between corruption and firm performance. Thus important omitted variables would be correlated with both corruption and indictors of firm performance, so that the corruption coefficient on the firm performance measure would be biased. ${ }^{6}$

Perceptions play a role in corruption assessment and should inform the econometric strategy used. McArthur (2002) argues that respondent's tendency to more or less complain will create a perception bias in the data. For example, respondents may be 'habitual pessimists' more likely to see an economy's weaknesses rather than its strengths, or have encountered a corrupt public 
servant immediately prior to the survey on which account they end exaggerating corruption.

To address these statistical problems, we follow Kuafman and Wei (1999) and McArthur (2002) by constructing a variable, KISRANI, from the survey question 'I am confident that the judicial system will enforce my contractual and property rights in business. To what degree do you agree with this statement?' (Question 11 section V). KISRANI is constructed by taking deviations from the means of the responses to this question, which are categorical responses ranging from 1 for 'Fully agree' to 6 for 'Fully disagree'. The inclusion of KISRANI helps test and control for this potential response bias.

The literature suggests that the growth of firms is subject to "Gibrat's law of proportionate effect". By this law, a proportional change in firm size is independent of the firm's size and the odds for firm growth do not dependent on the original size of a firm. The growth of a firm is also viewed as a statistical phenomenon that results from the cumulative effects of chance occurrences related to a horst of forces that operate independently. An outcome of this law is that the growth rates of firms of different sizes have the same probability distribution. This also concurs with Geroski's (1999) hypothesis that the growth of a firm is erratic 
and unpredictable. This is because most firms innovate only sporadically and only once in a while. The growth of firms mimicks these erratic innovations.

The growth of a firm may also proceed in accordance with the Jovanovic hypothesis that postulates an inverse relationship between the age of a firm and its growth, with a disproportionate growth across cohorts of firms shaped by their age (Varyam \& Kraybill 1992). This hypothesis assumes randomly distributed shocks to cost functions with both time invariant and transitory components. Because of learning differentials among entrepreneurs, this model is important in understanding entry, exit or growth of firms. One prediction of the Jovanovic hypothesis is that the likelihood for business failure falls with firm age because older firms are better able to precisely estimate their true efficiencies. There are two important implications of this hypothesis. First, the growth rate of surviving firms converges with firm age. Second, controlling for firm age, the failure and growth rates of surviving firms are negatively related to firm size. Where production technology is such that firm output is a convex, decreasing function of managerial inefficiency, young firms will, according to Jovanovic hypothesis, grow faster than older ones. Furthermore, the share of small firms should grow 
when the birth rate of firms increases. This is because new firms tend to start small (You 1995).

We can also view firm growth through the lenses of the "Penrose effect" according to which the management capability of a firm puts a limit on its achievements (Penrose 1959). Lack of appropriate management has the potential of constraining firm growth. Differences in the quality of management therefore partly account for differences in the growth prospects of firms. This fits neatly with the argument that business persons with better managerial capability encourage firm growth while less endowed entrepreneurs eventually close down their firms and get absorbed as workers in firms with better entrepreneurial abilities. The converse is also true: managerially able workers eventually move from employment to form businesses (Liedholm \& Mead 1991).

The way entrepreneurs respond to risk sorts them out, with an entrepreneurial group emerging from the group of risk takers while risk averse individuals become workers (McCormick 1993). Risk averse entrepreneurs often prefer meagre but certain returns to high but variable ones, or reflect a 'safety first' stance by securing pre-determined income thresholds. Rather than desiring to grow, some entrepreneurs may be just happy to keep their enterprises small (O'Farell 1988; Hitchens, 1988). This state of 
affairs is more probable when future enterprise goals of ownermanagers are determined by personal life-styles and family considerations. Preference for survival rather than growth is more appealing when economic independence is the primary objective of the entrepreneur. A growth strategy often dilutes property rights over a business, so that many owner-managers and partnerships may choose to remain small to preserve ownership. Others shun firm growth simply because it makes their operations more obtrusive and more likely to attract attention from the wrong quarters such as competitors and tax authorities.

Nevertheless, when firms are able to grow, the growth dynamic releases their wealth and employment creation potential. Lack of such growth is therefore counter-developmental. Enterprises that do no grow deny society the developmental outcomes of a vibrant private sector, so that failure to grow should attract policy attention.

Exports of manufactures are also important in the expansion of industrial production and economic growth (Graner and Isaksson 2002). This is because such exports encourage competitiveness, productivity and firm-growth prospects. Participation in external markets permits exploitation of economies of scale that often generate domestic spill-over effects related to employment and 
enhanced use of domestically available materials, encouraging downstream economic activity. Often, exportation of manufactures diversifies trade that is important for stabilising an economy since exports of manufactures are less prone to trade shocks. There are also learning-by-doing benefits since exporting firms adopt international best practices. They also receive feedback from international competitors and clients. There are also knowledge spill-overs that arise from involvement in external markets.

Firms are often better able to improve their product offerings when they have an opportunity to interact with foreign clients. Because exporters face stiff competition from foreign firms and have to satisfy exacting demands from foreign customers, they are forced to remain on the lookout for ways of improving product quality and production and delivery schedules. For these reasons, the benefits that Kenya and its firms can derive from exporting are phenomenal. It is for this reason that many export platforms were mounted in the last two decades in order to leverage Kenyan exports.

We measure the growth of firm through employment and create a growth variable by comparing employment in 2002 and three years previously. Our measure of growth is therefore short term 
and contemporary to other firm-level variables. We then apply OLS to estimate extended firm growth functions. Note that corruption variables are instrumented by their sector-location means to deals with the statistical pathology associated with endogeneity as argued earlier. We also include the variable, KISRANI, to test and control for perception biases.

The results (Tables 7) show that corruption, however measured, has a deleterious effect on firm growth. Firms that make more unofficial payments either as a proportion of total annual sales, for utilities, licenses, and a proportion of the value of government contracts grow less. We can therefore conclude that corruption has a stranglehold on the growth prospects of firms. The results also shatter the Jovanovic hypothesis about an inverse relationship between firm age and growth, as well as Gilbrat's law that the probability that a firm grows does not depend on it original size. Manufacturing firms based in Kenya seem to operate within a threshold where they have to live long enough to ever grow. Similarly, smaller firms seem to grow significantly faster than the larger ones as evidence of a catching up process.

The export propensity results are summarised in Table 8 , and show that corruption significantly reduces the likelihood for firms to export. In other words, firms that are more exposed to 
IDS Working Paper No. 541

corruption find it hard to participate in external markets. This finding is robust to different model specifications. We conclude that corruption not only stunts firms but also makes them less likely to export, denying Kenya the development benefits of firm growth and export participation. 


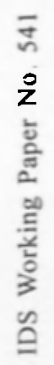

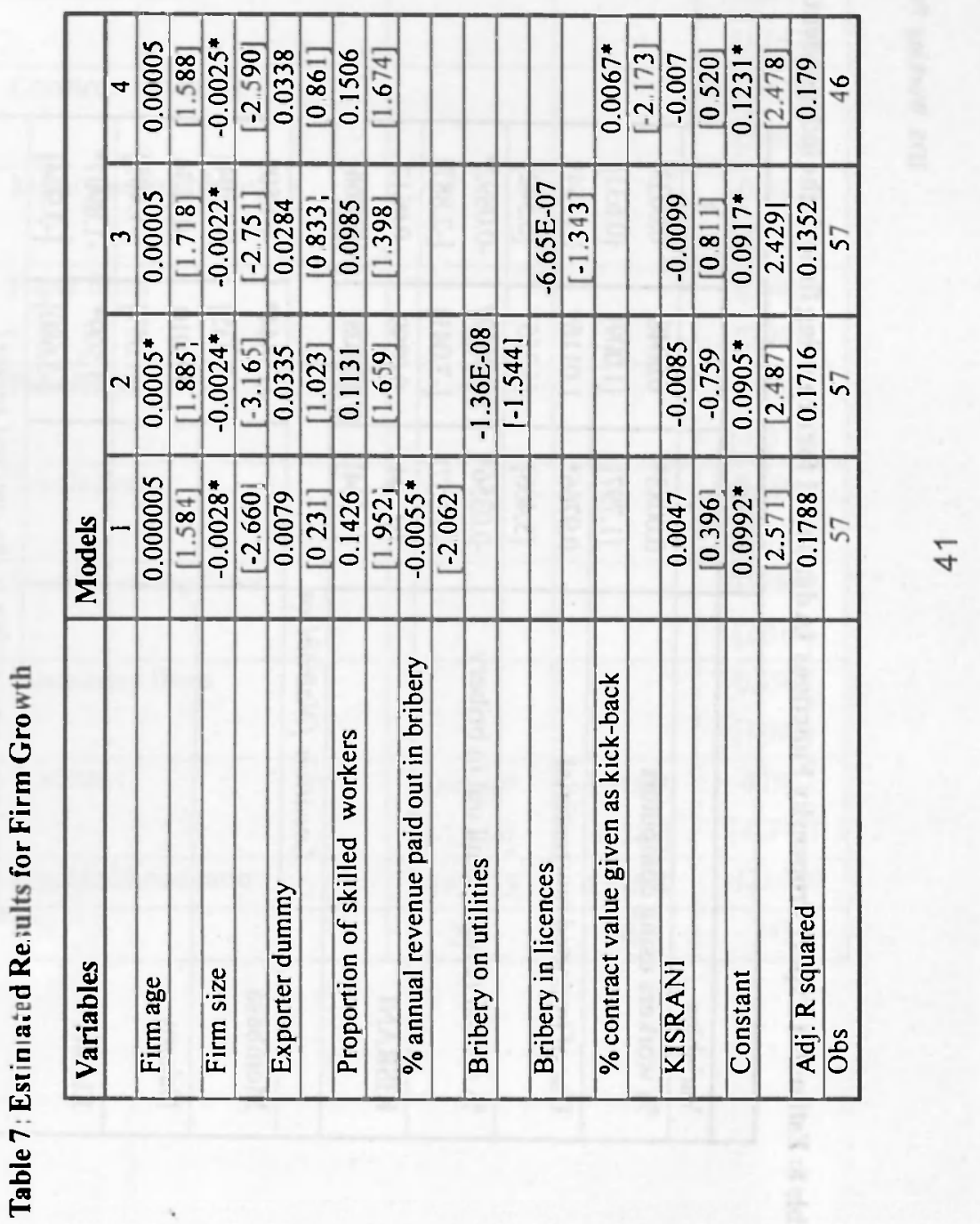


IDS Working Paper No. 541

Table 8: Estimated Export Propensity Functions [A dummy=1 for exporting firms is the independent variable]

\begin{tabular}{|c|c|c|c|}
\hline & Models & & \\
\hline Variables & 1 & 2 & 3 \\
\hline$\%$ workers using computers & $\begin{array}{c}0.0085^{*} \\
{[1.797]}\end{array}$ & $\begin{array}{l}0.0048 \\
{[1.009]}\end{array}$ & $\begin{array}{l}0.0033 \\
{[0.631]}\end{array}$ \\
\hline Use of imported raw material & $\begin{array}{c}0.9766^{*} \\
{[5.406]}\end{array}$ & $\begin{array}{l}1.0116^{*} \\
{[5.355]}\end{array}$ & $\begin{array}{l}1.1754^{*} \\
{[5.542]}\end{array}$ \\
\hline$\%$ annual revienue paid out in bribery & $\begin{array}{c}-0.0356^{*} \\
{[-2.167]}\end{array}$ & $\begin{array}{c}-0.0567^{*} \\
{[-3.041]}\end{array}$ & $\begin{array}{c}-0.0892 * \\
{[-2.887]}\end{array}$ \\
\hline KISRANI & $\begin{array}{c}0.0994 \\
{[1.534]}\end{array}$ & $\begin{array}{l}0.0399 \\
{[0.608]}\end{array}$ & $\begin{array}{c}0.0617 \\
{[0.868]} \\
\end{array}$ \\
\hline \multicolumn{4}{|c|}{ Location [Nairobi or } \\
\hline Mombasa & & $\begin{array}{c}-0.5844^{*} \\
{[-2.435]}\end{array}$ & $\begin{array}{l}-0.650^{*} \\
{[-2.504]}\end{array}$ \\
\hline Nakuru & & $\begin{array}{l}-0.3010 \\
{[-1.057]}\end{array}$ & $\begin{array}{l}-0.4534 \\
{[-1.405]}\end{array}$ \\
\hline Eldoret & & $\begin{array}{l}-1.509^{*} \\
{[-3.680]}\end{array}$ & $\begin{array}{c}-1.8907^{*} \\
{[-3.904]}\end{array}$ \\
\hline
\end{tabular}

\begin{tabular}{|c|c|c|c|c|c|c|c|c|c|c|c|}
\hline 8 & 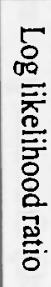 & 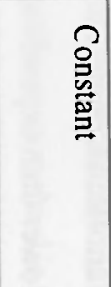 & 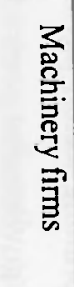 & 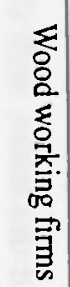 & 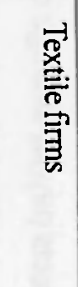 & 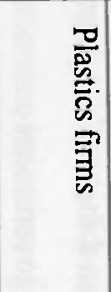 & 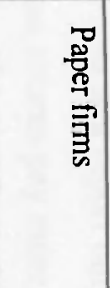 & 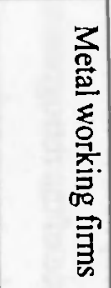 & 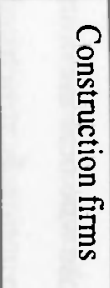 & 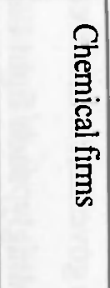 & 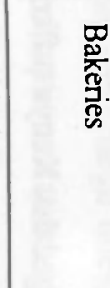 \\
\hline$\tilde{\omega}$ & 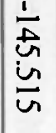 & 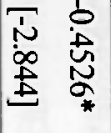 & & & & & & & & & \\
\hline E & $\begin{array}{l}\frac{1}{\dot{\omega}} \\
\dot{0} \\
\dot{0} \\
0\end{array}$ & 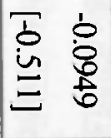 & & & & & & & & & \\
\hline & $\begin{array}{l}\dot{1} \\
\widetilde{N} \\
\dot{\phi} \\
\dot{0}\end{array}$ & 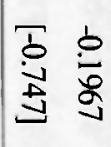 & 5 영 & $\begin{array}{l}\infty \\
\infty \\
\infty \\
\infty\end{array}$ & 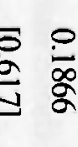 & 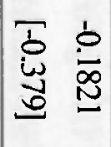 & 总悥 & 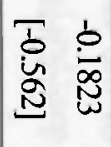 & 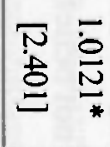 & 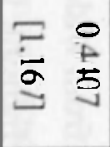 & 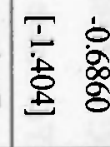 \\
\hline
\end{tabular}




\section{Conclusions}

For some time now, it has been acknowledged that Kenya suffers from widespread corruption. Although the government has been fighting the vice and has legislated accordingly, such fight has not benefited from hard evidence about those who bear the brunt of the vice or even how exposure to corruption is structured. There has also been very little clear evidence of the retrogressive consequences of corruption.

Using firm-level data, we have demonstrated that, although not all manufacturing firms in Kenya receive government contracts, those that are lucky to receive such contracts pay an average of $14.2 \%$ of the total contract value in kick-backs to public servants. There are huge sector differences around this mean, with the construction materials and the paper and printing sectors paying more than $25 \%$ of the contract value on government contracts as kick-back. The average expenditure on unofficial payments is $7.5 \%$ of annual sales. This is only a little lower than expenditure of allowances and adds to the cost borne by firm through theft, vandalism and arson.

There are also important firm size and location differences in the exposure to corruption. Firms based in Nairobi and Nakuru are more exposed than those based elsewhere. Similarly, the small and medium sized firms are more exposed than the very small 
and very large ones, so that the firm size and exposure-tocorruption relationship has an inverted ' $U$ ' shape.

The results show that the characterisation of corruption remains a non-trial task, but that in any case there is strong positive association between exposure to corruption and incompleteness in tax reporting, number of politicians closely known and red tape. Firms that report only a small percentage of their revenues for tax returns pay more on bribery, so that incomplete tax returns open a doorway for extraction of bribery, challenging the wisdom of under-reporting of tax obligations. The results also reveal that firms that pay bribery also face red tape, shattering the greasing function and efficiency theories of corruption. Corruption in the Kenyan context does not fast-track public services.

More significantly, corruption reduces the ability of firms to grow and penetrate external markets. Although Kenya has many export platforms mounted in the last 15 years, such platforms are unlikely to have outcomes that are true to their breed due to corruption. Reducing the incidence of corruption is likely to have a higher payoff than any of the platforms currently found in Kenya. Corruption also denies Kenya the development potential associated with firm growth. Although development thinking is shifting considerable responsibility to private enterprise, the potential development dynamism of private enterprise in Kenya 
is pitted against systemic corruption, so that the private enterprises' development outcome is constricted. We conclude that corruption in Kenya reduces returns to investment and investment rate, employment and wealth creation opportunities.

These firm-level findings add to the burgeoning literature demonstrating the retrogressive consequences of corruption, and provide further reason for intensifying the fight against the vice. That fight must however target specific sectors and locations. Additionally, there is policy value in continuing to rationalise the number of licenses needed to operate in Kenya and explore ways of dismantling bureaucratic discretion and control rights. Issuance of licences should continue to be decentralised so that businesspersons can procure these across the counter along with other services such as postal services. This should be the ultimate goal of decentralization of public services.

The programme of privatisation of state corporations and utility companies should be sustained to create further opportunities for expanding services, ameliorating capacity restrictions, service stretching and injecting competition in service provision. This will reduce artificial excess demand, and dissipate rents that are objects of bribery. Privatisation should also improve accountability and rights of ownership of state-corporation, both of which remain crucial in reducing corruption. 
IDS Working Paper No. 541

\section{References}

Bardhan, P. (1997), 'Corruption and development: A Review of Issues'. Journal of Economic Literature 35:1320 - 1346.

Bigsten, A. and Kimuyu, P. (2002), The Structure and Performance of Manufacturing in Kenya. Oxford, Palgrave.

Bliss, C. and Di Tella., R. (1997), 'Does Corruption Kill Competition' Journal of Political Economy 105(5): 1001 - 1023.

Cooksey, B.; Mullei, A. and Mwabu, G. (2002), 'Forms and Causes of Corruption' in Mullei, A. (ed.) The Link Between Corruption and Poverty: Lessons from Kenya Case Studies. The African Centre for Economic Growth and the United States Agency for International Development.

Fisman, R. and Svensson J. (2000), Are Corruption and Taxation Harmful to Growth: Firm Level Evidence Columbia Business School, Columbia University, New York and Institute for International Studies, Stockholm University, Sweden/ The World Bank, Washington DC.

Frye, T. and Shleifer, A. (1997), 'The Invisible Hand and the Grabbing Hand'. American Economic Associations Papers and Proceedings. 
IDS Working Paper No. 54 !

Geroski, P. (1999), The Growth of the Firm in Theory and Practice. CEPR Discussion Paper No.2092.

Kimuyu, P. (1997), Enterprise Attributes and Corporate Disputes in Kenya. Discussion Paper No. DP.1997/01. Nairobi, Institute for Policy Analysis and Research.

Liedholm, C. and Mead, D. (1991), Dynamics of Microenterprises: Research Issues and Approaches. Gemini Working Paper No.12.

Marcoullier, D. and Young, L. (1995), 'The Black Hole of Graft: the Predatory State and the Informal Economy'. The American Economic Review. 85 (3) pp 630-646.

Mauro, P. (1995), "Corruption and Growth". The Quarterly Journal of Economics 110: 681-712.

McCormick, D. (1993), Risk and Firm Growth: The Dilemma of Nairobi's Small Manufacturers. Discussion Paper No. 291, IDS University of Nairobi.

O'Farell, P.N. and Hitchens, D.W.N (1988), 'Alternative Theories of Small Enterprise Growth: A Critical Review'. Environment and Planning 20: 1365-1383. 
Murphy, K. M.; Shleifer, A. and Vishny, R W. (1993), 'Why is Rent Seeking so Costly to Growth?' American Economic Association Papers and Proceedings 83(2): 409 - 413.

Penrose, E. (1959), The Theory of the Growth of the Firms. Oxford, Blackwell Scientific Publications.

Shleifer, A and Vishny, R.W. (1993), 'Corruption' The Quarterly Journal of Economics 108(3): 559 - 617.

Svensson, J. (2000), 'Who Must Pay Bribes and How Much? Evidence From a Cross-Section of Firms'. Policy Research Working Paper No. 2486, The World Bank.

Tsegaye, S. (2003), 'Strategies for Effective Coalition Between Government Organs And Local Community Associations In The Fight Against Corruption'. A draft report submitted to the coordinators of the 2003 International Policy Research Workshop on Local Government Development Organisations. March 2003.

Tanzi, V. and Davoodi, H. (1997), "Corruption, Public Investment and Growth". IMF Working Paper No. 97/139 Washington: The International Monetary Fund.

Varyam, J.N and Kraybill, D.S. (1992), 'Empirical Determinants of Firm Growth'. Economic Letters 28: 31-36. 
Wei Shai-Jin (1997), Why Corruption is Taxation on International Investors. The National Bureau of Economic Research Paper Working Paper 6030.

Wei Shai-Jin (1999), Corruption and Economic Development: Beneficial Grease, Minor Annoyance or Major Obstacle? Policy Research Paper No. 2048, Public Economics, Development Research Group, The World Bank.

You, J.II (1995), 'Small Firms in Economic Theory: Critical Survey', Cambridge Journal of Economics, 19: 441-462. 
IDS Working Paper No. 541

\section{End Notes}

'See Bigsten \& Kimuyu (2002)

2 About the time of the survey. KIPPRA was in the process of launching the Kenya Private Sector Alliance that brought separate private sector associations under one umbrella

${ }^{3}$ The citizens in this context can be seen as the principals and politician as the agents

${ }^{4}$ After all, it is excessive graft and fear of the predatory state that pushes firms ways from the formal economy

${ }^{5}$ Stories abound of how in order to remain in business, businesspersons in Nakuru had to participate in the head of state 's fund-raising activities to either obviate his displeasure or attract his favours perceived necessary for operating in Nakuru.

${ }^{6}$ Fisman and Svensson (2000) argue and demonstrate that the bias will be towards zero, leading to an underestimation of the effect of bribery on firm performance. 